\title{
Epiglottic Schwannoma: A Case Report
}

\author{
Dasari Samuel Deenadayal*, Dumpala Vidyasagar, Karuna \\ Department of E.N.T.-Head \& Neck Surgery, Yashoda Hospital, Hyderabad, India \\ Email: aarticlinic@yahoo.com
}

Received 9 July 2014; revised 11 August 2014; accepted 15 September 2014

Copyright (C) 2014 by authors and Scientific Research Publishing Inc.

This work is licensed under the Creative Commons Attribution International License (CC BY).

http://creativecommons.org/licenses/by/4.0/

c) (i) Open Access

\begin{abstract}
Most common site of schwannoma in larynx is aryepiglottic fold and false cords. Epiglottis involvement is rare. The ultimate diagnosis is based on the histologic demonstration of characteristic spindle cells with typical nuclear palisading and positive immunohistochemistry for $S$-100 protein, but negative for a-smooth muscle actin, CD34, and vimentin. Effective treatment is complete excision.
\end{abstract}

\section{Keywords}

Epiglottic Schwannoma, Verocay Body, Immunohistochemistry (IHC), S-100

\section{Introduction}

Schwannoma is a tumor derived from the Schwann cells which are embedded in the neurilemmal sheath as a multinucleated syncytial network [1]. Approximately 25\% to 35\% of all reported schwannomas occur in the head and neck region. However, schwannomas involving the larynx are rare [1]. Most of these schwannomas occur in the aryepiglottic fold or the true vocal folds. We are presenting a rare case of epiglottic schwannoma.

\section{Case Report}

A 40 years old male came to our out patient department with a complaint of foreign body sensation in throat and difficulty in swallowing, which was more to solids since 2 - 3 months. There was no breathing difficulty. He was non smoker and non alcoholic. Speech was normal.

Clinical examination revealed a mass on the laryngeal surface of epiglottis which was obscuring the view of vocal cords (Figure 1). Ear and nose examination was normal, trachea was central and no glands were palpable. Fibre-optic Pharyngolaryngoscopy (FLP) was done, which showed that lesion was limited to upper one-third of epiglottis. Vocal cords were normal and mobile. On the basis of the above finding the Microlaryngeal surgery

\footnotetext{
${ }^{*}$ Corresponding author.
} 
was planned for the patient.

After complete pre-op work up, the patient underwent trans-oral microscopic $\mathrm{CO}_{2}$ laser assisted excision of mass under General Anaesthesia. After the General Anaesthesia was given, the patient was put in Boyce position and a Klein Sauccer suspension laryngoscope was introduced. Operating microscope using a $400 \mathrm{~mm}$ objective lens was utilised for visualising the mass. The mass was fibrotic in feel. It was totally excised and sent for Histopathology examination (HPE). The glottis and sub-glottis appeared normal.

The HPE of the mass reported it to be a sub mucosal nodule composed of spindle to elongated cells having eosinophilic cytoplasm and elongated nuclei. Stroma showed collagen and myxoid change. Focally pallisaded nuclei with verocay body were present (Figure 2(a)). The immunohistochemistry (IHC) was S-100 positive (strong diffuse nuclear positivity) and HMB-45 negative (Figure 2(b)). So, a diagnosis of schwannoma was opined.

The patient is under regular follow up and a FLP was repeated 1 month later which did not show any sign of recurrence.

\section{Discussion}

Neurogenic tumors of the larynx can be of two types: schwannomas and neurofibromas. Both entities are rare and comprise only about $0.1 \%$ to $1.5 \%$ of all benign laryngeal tumors [2].

Laryngeal schwannomas are usually isolated, although they have rarely been described in both type 1 and type 2 neurofibromatosis [3].

They were first described by Verocay in 1910 who called them neurinomas [1]. Schwannomas involve males and females equally and can occur at any age [1]. They usually involve the supraglottic larynx and may have an insidious clinical course. The most common nerve of origin for of laryngeal schwannoma is medial ramifica-

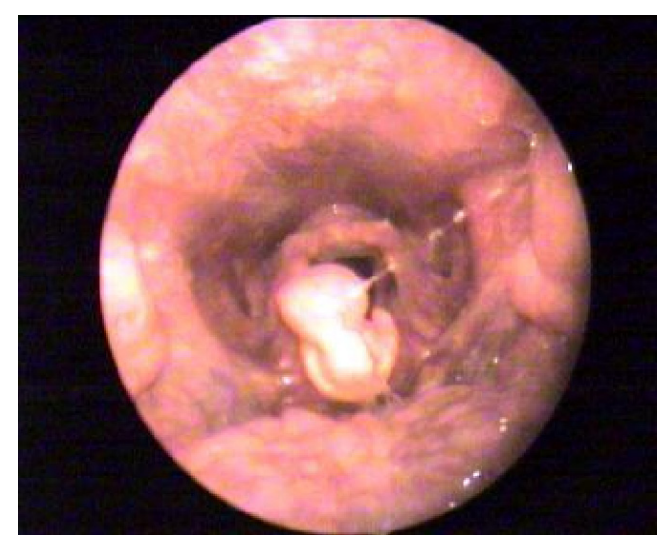

Figure $1.70^{\circ}$ video-endoscopy picture of larynx.

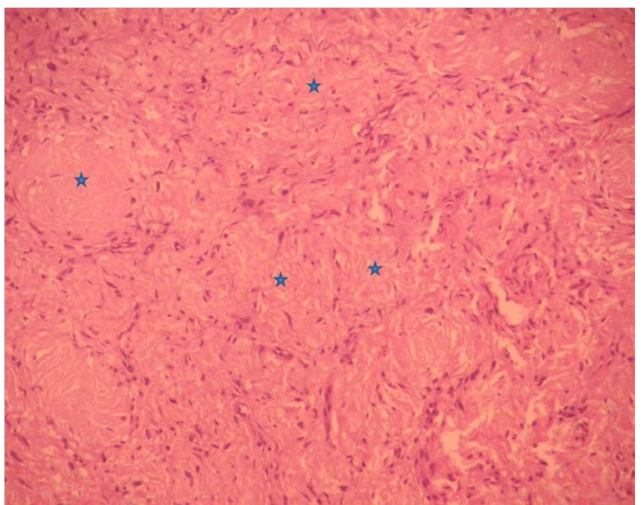

(a)

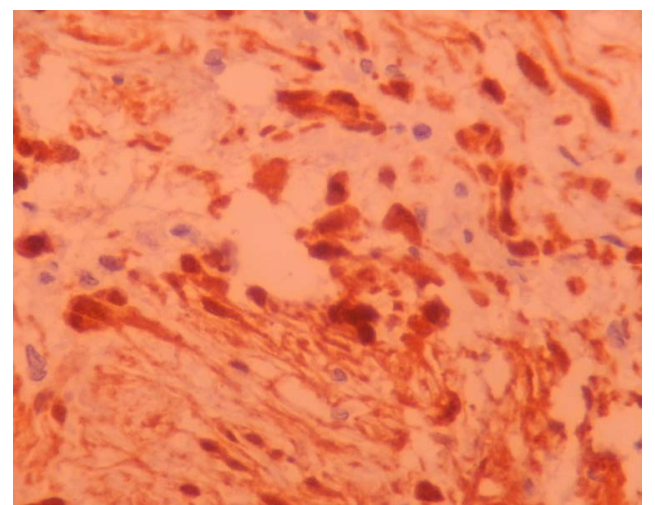

(b)

Figure 2. (a) Spindle to elongated cells having eosinophilic cytoplasm, focally palisaded nuclei showing verocay body; (b) Immunohistochemistry (S-100 positive). 
tions of the internal branch of the superior laryngeal nerve [3]. The tumor mainly involves the aryepiglottic folds (80\%), the vestibular folds (20\%), or extends to the pyriform fossa, whereas the subglottic region is uncommonly involved. Involvement of the true vocal cords is extremely rare [3] [4].

Laryngeal schwannomas may approach a large size, causing upper airway obstruction, dysphonia and even vocal cord fixation, depending on their location [5].

Histologically, two types of tissue are seen: 1) Antoni A tissue-compact groups of spindle cells with nuclei that tend to show palisading; 2) Antoni B tissue-loose reticular tissue, sometimes cystic. A portion of the tumor usually has cells with an interlacing, fascicular pattern while in other areas, there is palisading [4]. They show positive immunohistochemistry (IHC) for S-100 protein, but negative for smooth muscle actin, CD 34, and vimentin [3].

The most common differential diagnosis is Papilloma (85\%), but it tends to arise anteriorly in the true or false cord and extend to the subglottic space. Chondromas (5\%) arise from cartilage and often contain calcification. Other benign laryngeal lesions include hamartomas, choristomas, teratomas, lymphangiomas, and juvenile xanthogranulomas, adenoma, laryngeal cysts, internal laryngocele. In our case epiglottic cyst was major differential [3].

The ultimate diagnosis is based on the histological examination and immunohistochemistry [3].

Treatment of laryngeal tumors is largely determined by the histopathologic features, size, and location of the tumor. Complete excision has good prognosis. Malignant transformation is rare in schwannomas [5]. Schwanomas are highly radio-resistant, and hence radiation has no role [1].

\section{Conclusion}

The most common site of schwannoma in larynx is aryepiglottic fold and false cords. Epiglottis involvement is a rare site. As reported in this case, diagnosis is based on histopathology and IHC. Complete excision is the treatment of choice.

\section{Acknowledgements}

The authors acknowledge the invaluable input of Dr. Milap Shah, consultant pathologist at Yashoda Hospital, Secunderabad, India in providing the Histopathology and Immunohistochemistry report.

\section{References}

[1] Lone, S.A., Khan, M.A., Lateef, M. and Ahmad, R. (2004) Sub Glottic Schwannoma of the Larynx. JK Science, 6, 46-47.

[2] Ebmeyer, J., Reineke, U., Gehl, H.B., Hamberger, U., Mlynski, R., Essing, M., Upile, T. and Sudhoff, H. (2009) Schwannoma of the Larynx. Head \& Neck Oncology, 1, 24. http://dx.doi.org/10.1186/1758-3284-1-24

[3] Rognone, E., Rossi, A., Conte, M., Nozza, P., Tarantino, V., Fibbi, A., Saetti, R., Cutrone, C. and Tortori-Donati, P. (2007) Laryngeal Schwannoma in an 8-Year-Old Boy with Inspiratory Dyspnea. Head \& Neck, 29, 972-975. http://dx.doi.org/10.1002/hed.20616

[4] Rao, S.M., Chandra, S.T., Kumar, A.Y. and Murthy, P.S.N. (2011) Laryngeal Schwanomma Excision by Lateral Pharyngotomy. International Journal of Phonosurgery and Laryngology, 1, 37-39.

[5] Saita, V., Azzolina, A., Galia, A. and Fraggetta, F. (2005) Schwannoma of the Epiglottis: Case Report Focusing on Clinico-Pathological Aspects. Acta Otorhinolaryngologica Italica, 25, 378-380. 
Scientific Research Publishing (SCIRP) is one of the largest Open Access journal publishers. It is currently publishing more than 200 open access, online, peer-reviewed journals covering a wide range of academic disciplines. SCIRP serves the worldwide academic communities and contributes to the progress and application of science with its publication.

Other selected journals from SCIRP are listed as below. Submit your manuscript to us via either submit@scirp.org or Online Submission Portal.
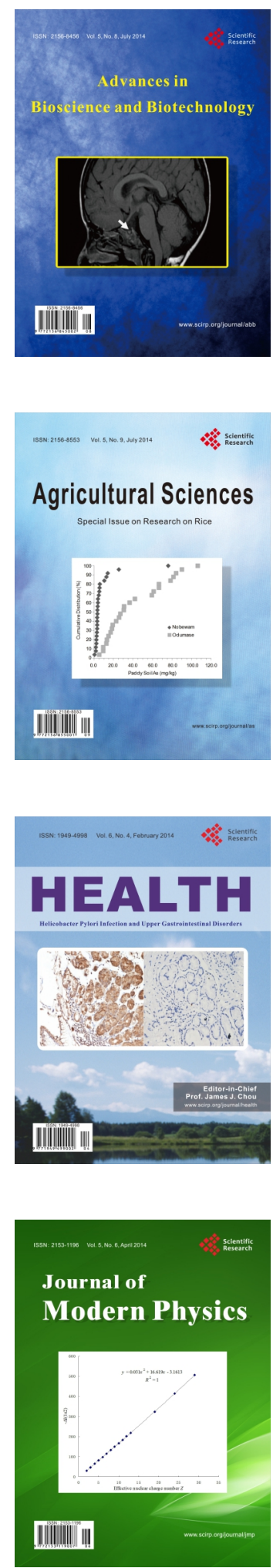
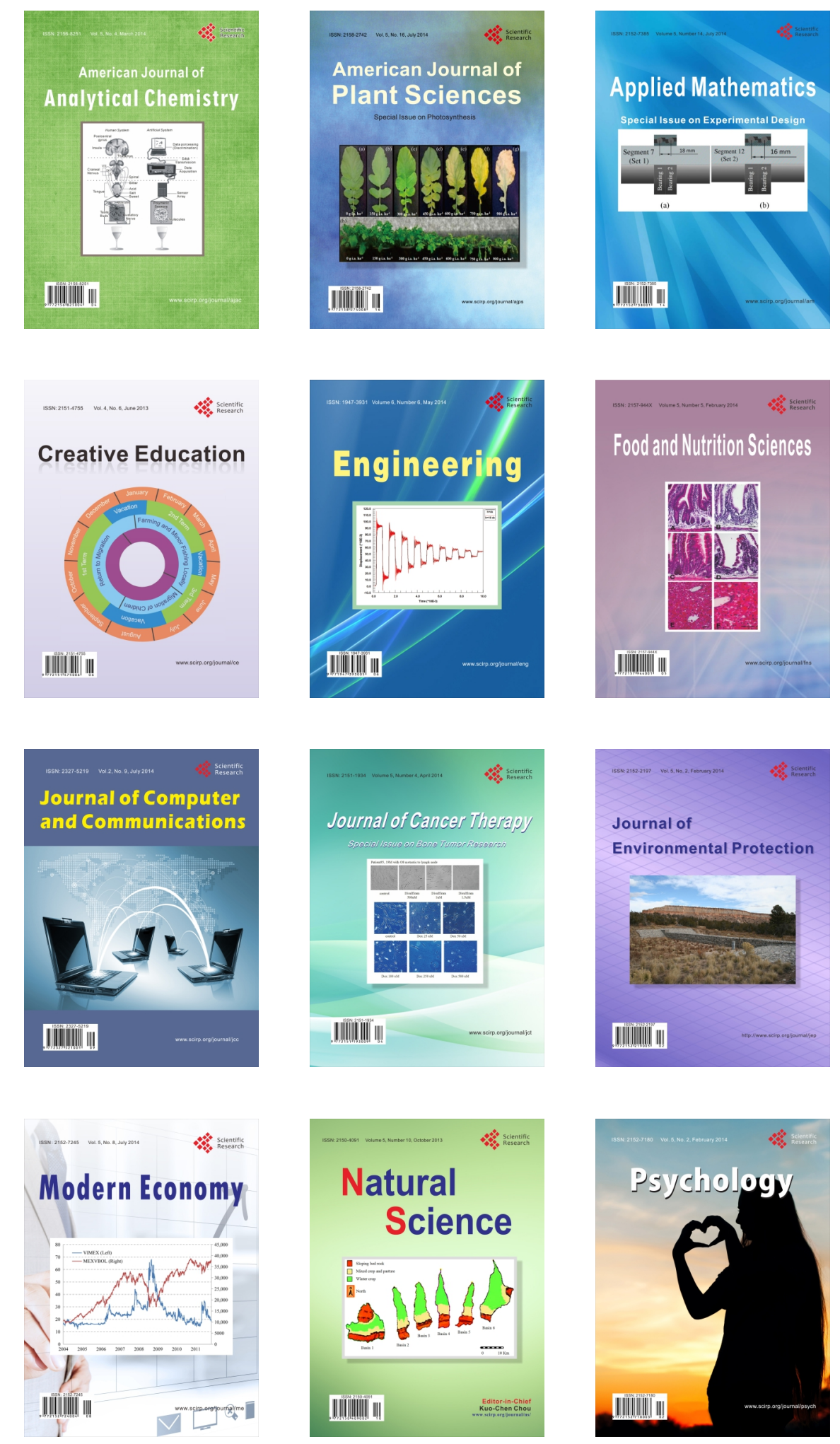